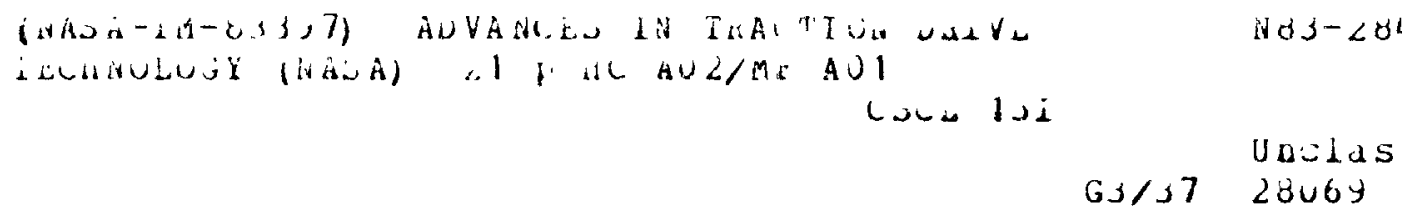

\title{
Advances in Traction Drive Technology
}

S. H. Loewenthal

Lewis Research Center

Cleveland, Ohio

and

N. E. Anderson

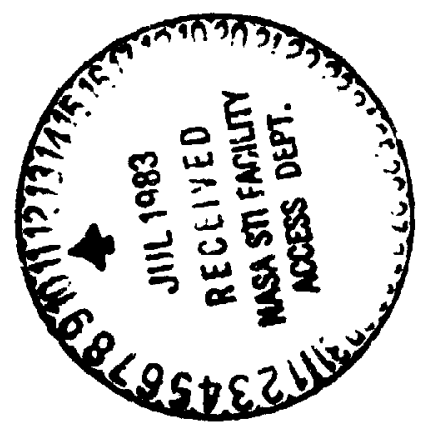

Propulsion Laboratory

AVRADCOM Research and Technology Laborateries

Lewis Research Center

Cleveland, Ohio

and

D. A. Rohn

Lewis Research Center

Cleveland, Ohio

Prepared lior lite International Off-Highway Meeting and Exposition sponsored by the Society of Automotive Engineers Milwaukee. Wisconsin, September 12-15, 1983 


\author{
S. H. Loewenthal \\ National Aeronautics and Space Administration \\ Lewis Research Center \\ cleveland, ohio
and \\ N. E. Anderson \\ Pronulsion Lahoratory \\ AVRAuICM Research and Technoloay Laboratory \\ Lewis Research Center \\ Cleveland. Ohio \\ ก. A. Rohn \\ Nationa 1 Aeronautics anri Space Administration \\ Lewis Research renter \\ cleveland, onio
}

\section{ABSTRACT}

Traction drives are among the simplest of all speed chanaing mechanisms. Although they have been in industrial use for more than 50 years. their operating characteristics and performance capabilities are not widely known. This paper briefly traces their technical evo-

\& lution from early uses as main transmissions

$\because$ in automoblles at the turn of the century to modern, high-powered traction orives capable of transmitting hundreds of horsepower. Recent advances in technology are described which onable today's iraction drive to be a serious candidate for off-hlohway vehicles and helicopter applications. Improvements in materials, traction fluids, desizn techniaues, power loss and life prediction methods will be highlighted. Performance characteristics of the Nasvyt is fixed-ratio drive are given. Promising future drive applications, such as helicopter main transmissions and servo-control positioning mechanisms are also addressed.

FRICTION WHEELS OF UNEOLIAL DIAMETER were one of the earliest speed changing mechanisms. It is speculated that their use even predates that of gearing "toothed" wheels, whose beginnings date back to the time of Archimedes, circa 250 B.C. (1). Even today, friction drives may be found in equipment where a simple and economical soil. inn tc speed requilation is reoutred. Phonograon drtves, self-propelled lawnmovers. or even the amusement park ride driven by a rubber tire are a few of the more common examples. In these examples, simple dry con-

Wumbers in parentheses designate references at end of paper. tact is involved and the transmitted pnwer levels are low. However, this same principle can be harnessed in the construction of an ofllubricated, all steel component transmission which $c$ an carryhundreds if horsepower using today's technology. In fact, oll-lubricated traction drives have been in industrial service as speed regulators for more than 50 years. Despite this, the concept of transiltting power via traction is not widely known or understood. Although traction drives have been available for some time $(2-6)$ it is perhaps since the mid 1960's or so that they have been considered serious competitors to conventional mechanical power transmisstons. The earlier Arives, particularly those targeted for autonotive applications, had the ir share of durabllity jroblems above nominal power levels. As a conseouence, relat ively few succeeded in the market place. The underlying reason for $\therefore$ is was that certain critical pieces of technoluay were generally lacking. Designs were based on mostly trial and error. No uniform fallure theories were available to establish service life or rellabllity ratings. The drive materials of the day were crude by today's standards. In short, traction drives were in their technical infancy.

Prompted by the research for more efficlent automotive transmissions and bolstered by advancements made in rolling-element bearing technology. ir.:erest in traction drives has been renewed. Today's analytical tools, materials, and traction fluids are far superior to tho a avallable prior to the 1970s. This has led to the re-emergence of traction drives ind the technology related to their design. It is the intent of this review to discuss the baste principles of these traction drives and to trace the evolution of the ir techmology, in a linited sense, from the ir early development to the efforts underway today. 


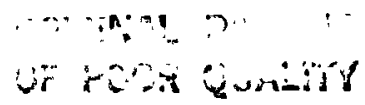

\section{EARLY APPLICATIONS}

One of the earliest known examples of a friction* drive is that patented by $C$. W. Hunt in 1877 appearing in Fia. 1 (6). The Hunt drive had a single, spoked transfer wheel that was probably covered with leather running against a pair of toroidally shaped metal disks. Judging by the pulley flanges attached to the toroidal disks, the drive was intended to regulate the speed of belt-driven machinery such as that commonly found in factories at the turn of the century.

A similar drive was devised by $w .0$. Hoffman as shown in an 1899 British patent application (7) (Fig. 2). The toroidal drive arrangement apparentiy found great favor with traction drive designers through the years. Work continues on this configuration even today, more than 80 years later.

Friction drives also found use on several types of wood-working machinery dating back before the 1870's. For example, Appleton's Cyclopedia of Applied Mechanics (8), published in 1880 , reports of frictional gearing being used to regulate the feed rate of wood on machines in which one wheel was made of iron and the other, typically the driver, of wood or iron covered with wood. For driving light machinery, wooden wheels of basswood, cottonwood, or even white pine reportedly gave good results. For heavy work, where from 30 to $45 \mathrm{~kW}$ was transmitted by simple contact, soft maple was preferred.

AUTOMOTIVE SERVICE - It was not unt il the introduction of the horseless carriage at the end of the 19th century that the goal of developing a continuously variable transmission (CVT) for a car sparked considerable friction drive activity. Mechanical ratchet, hyAraulic, and electro-mechanical drives were all tried, but dives relying on friction, because of their simplicity, were the first automoblle tran!misstons to provide infinite ratio selection. The earliest of these was the rubber $V$-belt drives that appeared on the 1886 Benz and Daimier cars, the first mass-produced gasoline-engine-powered vehicles. Friction disk drives were used as regular equipment on a number of early motor cars, such as the Lambert as 11lustrated in a 1907 advert isement (9) (Fig. 3). Others included the 1906 Cartercar, 1909 Sears Motor Buggy, and 1914 Metz Speedster.

The term "friction drive" is nomally used to refer to a drtve that is nonlubricated wile "traction drive" refers to one with ofl-wetted components. The friction terminology may have evolved from the fact that these drives intentionally use at least one roller that was covered with a high friction materlal such as leather, rubber. fiber or even wood. This not withstanding, the term "friction" is soment of a misnomer since it is still the traction force responsible for positive motion of the driven element.
The Cartercar had an extre...'y simple friction drive consisting of a metal disk driven by the engine crankshaft, in friction contact with a large, fiber-covered spoked wheel mounted on a transverse countershaft. To vary speed ratio, a driver operated lever was used to radially position the output follower wheel across the face of the metal disk - turntable fashion. The smoothness and ease of operation of the Cartercar transmission made it quite popular. It is not well-known that $\mathrm{Mr}$. W. C. Durant, founder and first president of General Motors Company, acuulred the Cartercar Company in 1908 because of his expectation that frictiol. drives would soon be universally used in automobiles $(10,11)$. In 1910, the Cartercar Company even produced a Model "T" truck, equipped with their friction drive. Despite its catchy sloqan. "No clutch to si ip - no gears to strip .... a thousand silent speeds and only one control lever, that 's a Cartercar", ine Cartercar Company's commercial success was shortlived.

From 1909 until 1912, Sears marketed a two-cylinder, 14-horsepower "Motor Buggy", also eoufpped with a friction drive (12). mabsolute simplicity, its positiveness under the most severe conditions and its unequalled flexibility", boasted one of the Sear's ads. However, by about 1915, cars equlpped with friction drives had virtually disappeared (12), presumably due, in part, to the need to freouently renew the friction material Despite the limited success of these earlier attempts, the goal of dee , ing and automotive transmission that $\operatorname{sm}, 0 . \mathrm{hl}^{\mathrm{l}} \mathrm{y}$ and automatically shifted was not lost. In the late 1920 s the Buick Division of General Motors was given the task of developing a cont inuously variable, oil-lubricated, steel-on-steel traction drive. This transmission was similar in design to the Hayes double toroidal traction drive, patented in 1929. The Hayes SelfSelector Transmission (13), although orginally developed in the United States, was later offered as an option on the 1935 British Austin Sixteen (14).

The General Motors toroidal drive, later called the toric transmission. is fllustrated in Fig. 4. The geometry of the drive is remarkably similar to the 1877 Hunt drive, with the addition of a second toroldal cavity and a ball differential to balance loading between the two cavities. An extensive test progran was condicted on this drive. Seventeen roadtest vehicles equipped with the toric orive accunulated over 300,000 milles of road testing (11). A 20-percent improvement in highway fuel mileage was reported. In 1932. General Motors decided to produce this type of transmisston (10). However, no cars eaulpped with the toric drive were ever sold to the public. The reasons for halting production were never really made clear. Some say that there were unresolved discrepencles in service life data obtained during road tests and that obtained from laboratory bench testers. others belleve 


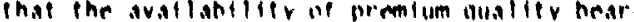

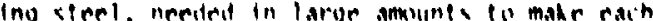
drive. was simule nile great moligh at the time

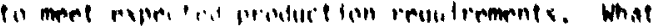

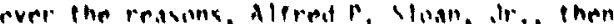

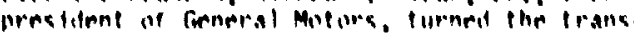

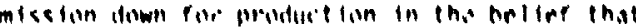
t1 wulit simoly he too expenclye to mate (III).

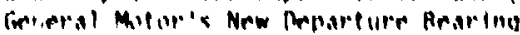

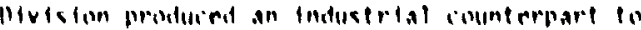
the forle detue, Ar 1916 when prouluet ton was

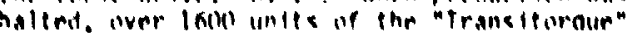

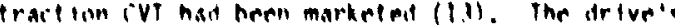

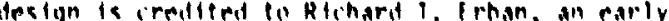

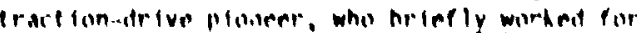

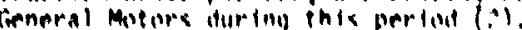
In [nuland, offer several rears of and

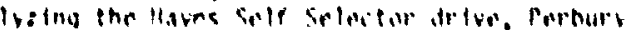

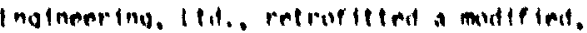
scrapned Maves transmisston ines Milliman Mins sedan in 104a (14). I unl savlnus were remorted to br ill is prevent hut the comerent really never teaught un with any of the several dogen cumantes ur so that hat exturessed initial inferest in the trive (14). in the linterd itales in lonv, charles

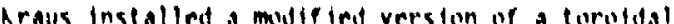
CVI Into an Amertican Motiors Nash Rambler $1:$. Inis unit had a smi-ferolital roller umometry stmilar on that datented in 10,3 hy Jacon Arler for induserial servire. The Arter at ive is still commercially prodiced in switzerland. In 107. Iractur. Ine. Aemenserated a ford Pinto coulphed with an improved veretion of the Rraus drtue lubrlicaled with Monsanto's then new trac tion fluld. Althowoh onerat lonal iharacteristice were estahlished, expected fuel econionv improvments mere laroely neoated by the hytraulis losese in the thrust hearinas used to clamp the torolds together (15). More recent corodial drive destons nartially overesen this

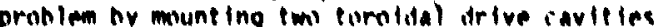
hack-to-bart. Alono a common shaft, thereby - liminafing those troublesome thrust hearinos. INOISTR tAL SFRVICF . Start ing with the 18): Hunt drive, ad,luctahle-speed iraction drives have heen in Industrial service for mare than im rears. The hult of these drtyes has hoon performing a sped matehing function for llohe-duty equlpment. such as drtll presses. A sample of rearesentative traction drive conflgurations apposers in Fia. 5. According en Carson's 109s artlete (1K) mare than $1(0$ Unterd States patents on adjustable-speed trection drives are on flle. Out of these, perhaps - dozen or so hasic geanetries are in produc -

ton. of those comerielly avalloble for ar rated ot oroater than in pin power capacity. An early review of the baste types of adjustablesoeed traction drives can be found in $(1)$ heference if glves descriptive information on 24 tyoes of vartable speed truction drives that we comercially avallable in 19a3.

Applicallons for modern iroction drives are outte diverse ranging from machime tools, textlle achimory to converor and pum drives. Spacifle applications can be found in $(8-4,16,17)$.
AASli PRINI IPISS OF IPFRAIION

FiAllars - Iraction drives ran be ronsirueterl fl gture a single. Mexed-spend rallo, like s uearhox or unlithe a gearbox. speed raflu that in ho cont inuous ly varled by us ing sinn mans ta shift or lilt rollers so they enuage at different rolling radil. This latter arrangrment is of extrme interest to trive irain conel laurators since il provides them with en escentlally "infinile" number of shlfe boines fo obt imiee thr performance of their drive sustem.

Apiause nower iransfer nccurs hetwen smoith rolling-bodies, qonerally across thin. tenailous luhrirant film, traction drives poserss certain performance characteristics not found in wthel puwar transmisstons. Iraction Irives can be deslaned lo smouthly and cont Inunius lo vary the spered ratio with effictenc les approaching those of the hest gear drives. lintikn Iransmiscions with gear teath, which. even when norfectly machined, cenerate lorclonal ase tll lat ans as the load transfors hetwen terth, power transfor through traction is inherentiv smolith and oulet without any "nachlash". A luaricant flim trapped betwoon the rollers. tends to protect aqainst wear and (1) dampon torstonal vibrat tons. The operating speed of sime tractlon drives is limited anly hy the hurst strenuth of the roller material and the avatlable traction in the contact. In many iases, traction drives can be desionod to he as small as or smaller than thelr nontract lon-drive counterparts, When manufactured in sufftetent ouant ity. costs can also he autte compelitive because of the sinilarit tes in manufacturino traction drive camponents and urilinary mass-protuced ball and raller hearinas.

TRACTION PONER TRANSFER - A baslc under: Ianding of how power is transforred dotwen traction-drive rollers is helpful in reviewing the contributions made in ents area, Floure $f$ shows slmole, lubrlcated, roller pair in traction contact, A suffictont iy large normal load $A$ is imposed on the rollers to transult the tanoential traction force T. The count of nomal load reoulrad to transent o given traction force without destructive oross silo is dictated oy the avaliable traction cooffl. clent. $u_{0}$ wich ts the rat la of $T$ to N. since contect fat loue life is inverse $y$ related to the third power of normal load, it fe extrem iy destroble to mate use of iubricants that produce high values of $w$. The seareh for lubricants having hion traction capablittios wll be discussed later.

The rollers. as lllustrated in the onlared view of the contert apouping in Fig. 6. are not in direct contect but are, In feet, separated by a highly comprassed. extrumly thin lubricant film. Decouse of the presence of high pressures in the contect. the ivoricetion process is eccompanled by som lestle doformation of the contect surfece. Accord. 


\section{ORIGINAL PACE IS \\ OF POOR QUNLITY}

ingly, this process is referred to as elasto. nydrodynamic (FNO) lubrication.

This phenomenon Also ocrurs for othar oll-lubricated, rolling-element machine: ments such as hearings and gears. The importance of the EHn film in traction contacts lies in its abllity in reduce and/or el iminafe wear whtle aci ing as the principal toroue trans ferring medium.

TRACTION CIRYF - The tribolnolcal proper. tes of the luhricant in the contact. particularly tis traction characteristics. are fundamental to the desian of traction drives. Flqure 7 shows a Ivplcal traction-versus-si ip curve for traction fluid. This type of curve is troically generated with a twin-disk tract Ion tester. Imposing a tract lon force across - lubricated disk contact wich is rotating at an average surface velocity 11 qives rise to a Alfferential velocity all, somet imes referred "o as "rreep". Three distinct regtons can enerally he identifled on a traction curve. in the linear reaion the traction coefficlent increases linearly with slip. in the nonNewtonian reqions it increases in a nonlinear fashton, reaches a maximum, and then beqins to decrease. Finally, the curve shows a gradual decay with slip in the thermal reaion due to internal heating within the ofl film. It is the linear region of the eraction curve that is of the greatest interest to traction-drtice desioners. The deston tract Inn coeffictent. which dictates how much normal load is needed to transmit a given traction force, is lways chosen to be less then (oy, generally, 20 to 30 percent) the peak availible traction coefficlent to provide a safety marain agalnst sllp. Traction drives are generally eoulpped with a toroue-sensitive londing mechanism that adjusts the normal contact load in proportion to the transmitted torque. Such mechanisms insure that the contact will always have suffictent load to prevent slip without needlessly overloading the contact under llaht loads.

\section{AnVANCEMENTS IN TECHOLOGY}

Traction drive technology made relatively little progress for the first half of this century except for the occaslonal introduct ion of - new geametric variotion. Designs were largeiy predicated on laboratory or fleid experience and very little of this informat lon was reported In the open technical literature.

Because of the great sintlerity in the contect operating condition, traction-drive technology benef ited greatly from the wave of technical advancements made for rolling-i lement bearings. Major advancements in bearling deston occurred in the late 1940s with Grubin's work in elestohydrodyncicic libricat ion (19) and

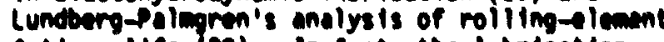
fat lgue life (20). In fact, the lubrication princtoles. coproting conditions, and fallure mechanisas of trection-drive contects and bearing contacts ore so sinflar that the design fundamentals are virtually interchangeable. The same may he sald for gear contact desion criteria as well.

In view of the durabillity shortcomings of earlier traction drives, much of the recent research has centered on improving the power capactly and rellabllity of these devices without sacrificing their inherent simplicity or high mechanical efflelency. Although work has heen performed on many fronts, research efforts to date can be loosely catequrlzed under one of several areas: (1) matielino the tractive be-

havior of the lubricant within the contact and Its attendant power losses: (2) predtcting the usef dl toruue that can be passed between rollers without surface distress or that anount corresponding to a given fat lque ilfe: (3) determining and tmproving the durablitity characteristirs of traction-drive materlals. primarlly hearino-arade steels; (4) developing lubricants that produce higher traction forces in the contact without sacrific ing convent ional lubricant oualities: and (5) deve ioping drive arrangements that maximize durability. corque capacity, and rat to capabllity and minimize size. welght. power loss and complexity.

CAPACITY - The earliest iraction drives generally used leather, wood, rubber, or fiber covered friction wheels running agoinst metal disks. As these soft friction meterials aged. they lost flexibility and wore rapldly. The driving surfaces aenerally had to be renemed or replaced at frequent intervals, depending on the rate of usage. Desplte this. Friction drives found use in early stem tractors, factory machininery, wood-working tools, and in several vintage cars. These simple, smooth, low-cost speed changers are stlli in use today for light-duty applicetions ranging frem hand to.jls, washing machines, and record plavers to amusewient park rides and cement mixers. In these modern dr lves more durable rubber and relnforced plastic materials have been substltuted for the leather and flber whenls of yesteryear. However, the thermal capactiy ant wer charecteristics of these softer materials still baslcally set the useful power capacity of this rlass of transaisston. For apolicatlons $n$ aling low-cost speed changer. adjustable-speed friction drives are good choices.

DII-lubricated traction drlves having hardened steel rolier contects apoured in the early 1920s. Carson (6) credits trban in Austris with the developient of the first milalo-tatal, ofl-iubricated drive in 1922 . The 1923 Arter orlve is another excople. The presence of hardened iteel rollers in these drives significantly increased the allowbite operating contect stresses. The purpose of the oll was to protect the contect surfeces from mar intle provlding cosiling. Howrer. the relativily tow cosfictent of trectien of the ofl ment that these or lues had to cerry unusually hlgh-contect loads to inmiblt sifp. High loeding gempolly leads to carly plteim. unlese the borave rating of the dive wes 
appropriately restricted. Even though the early traction orives tended to be bulky, their relatively high efficiency and smoothness of operation still made them attractive for many appl lications.

FATIGUE LIFE - In the past traction drives were basically sized for some allowable Hertz (contact) stress in the contact zone based on experlence. No concerted effort had been made to size traction drives for a certain fatique life such as the way ball and roller bearinas are sized. Hence, while most of the drives shown in Fia. 5 may function well under some conditions, reliability characteristics are generally not well defined. Their expected service lives have not been determined in a manner to allow for comparisons hetween differ ent types of drives or to predict the effect that widely varying operat ing conditions might have on fatique life.

The first modern approach to determining the durability characteristics of traction drives was that published by Coy, Loewenthal and Zaretsky in 1976 (2i). The ir analysis made use of the fact that the materials, operating stresses, lubrication conditions and fallure mechanisms, namely rolling-e lement fat ique, of properly designed traction drive contacts are virtually identical to those of ball or roller bearings. Thus the methods used to determine service ife ratings of rolling bearings. namely Lundbera-Palmgren Theory, should be applicable to sizing traction drives. Lundberg and Palmgren (20) theorized that the probability of encountering a subsurface defect in the material leading to fat laue pitting was stat istically related to the contact stress. the depth of the critical stress below the surface and the volume of materlal being stressed. In (22). a simplifled version of this fat igue-ilfe theory was developed for traction drive contacts and in (23) this method was used to show the effects of torque, size, speed, contact shape, traction coefficient and number of multiple, parallel contacts on predicted drive life. These investigations show that multiple, load-sharing contacts significantly benefit torque capacity and drive iffe. Also. torque capacity and drive life are proportioned to size to the 2.8 and 8.4 power, respectively as shown in $\mathrm{Fig} .8$. Figure 9 from (23) clearly ilustrates the importance that the ofl's coeffictent of traction has on performance.

TRACTION FLUIDS - Because of the twortance that the coefficient of traction has on the life, size, and Derformance of a traction drive, considerable attention has been given to ident ifying flulds with high traction propertles. starting in the late 50 s with lane's experiments (24). Hewko (25) obtained traction performance data mich Indicated that the lubricant composition and surface topography had the greatest overall effects on tractlon and that naphthenic-based mineral ofls gave better performance than paraffinte olls. Some of these early investigations lead to the development of comercial traction flutids.
The research of (26) describes the development of formulated traction fluid, designated as Sunoco Traction Drive Fluid-86. This fluid evolved into Sun 0il's TDF-88, a comercial traction fluid currently available on a limited basis.

Hamman, et al (27) in examining some 26 test fluids Identified several synthetic fluids that had up to 50 percent higher coefficient of traction, depending on test conditions, than those reported for the best naphthenic base ofls. This research latd the ground work for the development of Monsantc's family of commercial traction flutds, Santotrac 30,40,50 and $7 n$. These fluids are the most widely used traction ofls today. The results of accelerated rolling contact fatique tests $(28)$ indicated that these synthetic traction fluids have good fatique life performance, statistically comparable with the automatic transmission fluid used in this experiment.

A recent addition to the commercial traction fluid market is that produced by the Mitsubishi 0 il Co., Ltd. Their Dianond Traction Fluid is offered in three viscosity grades and is said to offer high traction coefficients. good wear and anti-oxidation properties.

It should be kept in mind that the use of traction fluids is not mandatory, although preferable. This is best lliustrated by the experiments of Gaggermeter (29) in which traction coefficients for 17 different lubricants were measured on twin-disk traction tester at both high and low contact pressures and surface speeds. The traction fluids in $h$ is tests showed substantially higher coefficients of traction than all of the commercial naphthenic mineral oils tested. The greatest differences occur at relatively low pressures and high surface speeds (fig. 10). At relatively high pressures and low speeds the traction fluids show less of an advantage. Under such conditions a good quality naphthenic mineral oll would serve almost as well. However, for most traction drive applications there is considerable incentive to using a traction fluid, with expected traction improvements falling somewhere between the two examples of $F \mathrm{Fg} .10$

MATERIALS - Earlfer traction drives were not exploited to their full potontial because of uncertaint les regarding their longterm reliability. The limited durability characteritics of the materials used in these drives was major contributing factor. The substitution of ofl-lubrlcated, hardened steel roller components in place of rubber or relnforced plastic running dry against cast-iron parts raises their load capacity by at least an order of magnitude.

Because of the sinflarity in operat ing conditions, hardened bearing steels are logical cholces for traction-drive rollers. Today's bearing steels are of significantly hioher ouality than the traditional ofr-melted, AISI 52100 steels used in rolling-element bearings since the 1920s. The introduction of vacuu remelting processes in the late 1950s has re- 


\section{ORIGINAL PAGE IS OF POOR QUALITY}

sulted in more homogeneous steels with fewer impurities and have extended rol'ing-e lement bearing life several-fold. Life improvements of eight times or more are not uncommon according to (30). This reference recommends that a iffe-improvement factor of six be applied to Lundberg-Palmgren bearing life calculations when using modern vacuum-melted A ISI 52100 steel. A simflar life-improvement factor is applicable to traction-drive life calculations. This improvement in steel oualfty in combination with improvements in liubricant traction performance have increased the torque capacity of traction drives several-fold.

PERF ORMANCE PREDICTIONS - The distribution of local traction forces in the contact of an actual traction drive can be rather complicated as illustrated in Fiy. 11. This figure shows the distribution of local traction vectors in the contact when longitudinal traction, misal Inement and spin are present. These traction forces will altne themselves with the local s:fp velocities. In traction-drive contacts some combination of tractions, misal inement, and spin are always present. To determine the performance of a traction-drive contact, the elemental traction forces must be integrated over the area of contact.

The power throughout the contact is determined from a sumation of the traction force components alined in the rolling direction times their respective rolling velocities. It is clear that in misalinement only a portion of the traction force is generating useful traction and that the remainder is generating useless side force. For pure spin no useful traction is developed, since the elemental traction forces cancel one another. Since the contact power loss is proportional to the product of the elemental traction forces and slip velocities, the presence of spin and misalinement can significantly decrease the efficiency of the contact. Furthermore, both conditions lower the avaliable traction coefficient and reduce the amount of torque that can be transmitted safely. Designs that $m i n i m i z e ~ s p i n$ and side slip can be autte efficient. Contact efficiency of 99 percent or higher are possible. THEORY - In the 1960s and early $70 \mathrm{~s}$, numerous papers were prcsented on the prediction of traction in EHD contacts. Poon (31) and Lingard (32) developed methods that integrated the contact forces to predict the available traction forces of a contact experiencing spin. Poon's method utflized the basic traction data from a twin-disk machine together with contact $k$ inematics to predict the aval1able traction. Lingard used theoretical approach in wich the EHD film exhibited a inewtonian viscous behovior at low shear rates until a critical limiting shear stress was resched. At this point the film ytelded plastically with increasing shear rate. This model showed good correlation with experimental traction data from a toroidal, variable-rat lo drive of the Perbury type. This same model was also successfully used by Gaggermeter (29) in an unusually comprehensive invest Igation of the losses and characteristics of traction drive contacts. In addition to coplous amounts of twin-disk traction data for numerous lubricants under various combinations of $s$ lip, sideslip. and spin, Gaggermefer (29) also invest taated the sources of power losses of an Arter type toroidal drive. His findings were that of the total power losses, the load-dependent bearing and drive idling (no-load) losses were always greater than the losses due to traction power transfer. This result underscores the need to pay close attention to these tare losses in order to end up with a highly efficient traction drive.

A recent and comprehensive traction contact model is that proposed by Johnson and Tevaarwerk (33). The ir model covers the full range of viscous, elastic, and plastic behavior of the EHD film. At higher pressures and speeds, typ: $\rightarrow$ of traction-drive contacts, the response of the lubricant film is linear and elastic at low rates of strain. At sufficlently high strain rates, the shear stress reaches

some limiting value and the film shears plasticaliy as in the case of some of the earlier analytical traction models.

In (39) Tevaarwerk presents graphical solutions developed from the Johnson and Tevaarwerk elast $\{c-p$ lastic traction model. These solutions are of practical value in the design and optimization of traction-drive contacts. By krinwing the initial slope (shear modulus) and the maximum traction coeffictent (limiting shear stress) from a zero-spin/zerosidesilp traction curve, the traction, creep. spin torque, and contact power loss can be found over a wide range of spin values and contact geometries.

Figure 12 shows that this analys is compares favorably with test data, taken from experiments of Gaqgermeler (29). The observed, pronounced reduction in the avallable traction coeffictent with just a few degrees of $\mathrm{m} / \mathrm{s}-$ al inement, underscores the need to maintain accurate alinement of roller components in traction arives.

FLUID TRACTION DATA - To be able to apply the aforementioned traction drive, certain fundamental flutd propertles, newely, the lubricant's shear modulus and 1 imiting yfeld shear stress, must first be known under the reaulred operating sneeds, pressures, and temperatures. Because of the difflcuity of simulat ing the highly transient nature of an actual traction contact, the most rellable basic fluid property data have been tradi. tionally deduced from the initial slope and maximum traction coefficient of an experimental traction curve. To obtain experinental traction data for destgn purposes, a MASA progra was conducted for both the Monsanto and Sun 011 traction fluids over a range of spaeds, pressures, temperatures, spin, and sldeslip values that intoht be encountered in trection drives (35). R regression enalys is applied to the date resulted in correlation equation that 
can be used to predict the initial slope and maximum traction coefficient at any intermediate operating condition (36).

\section{RECENT DEVELOPMENTS}

During the past 5 years, several traction drives, which incorporate much of the latest technoloay, have reached the prototype staqo. Laboratory tests and desian analys is of these drives shows them to have relatively high-puwer densities and, in some cases, to be ready for commercialization.

NASVYTRAC DRIVE - Although light-duty variable-ratio traction drives have been reasonably successful from a commercial standpoint, very few, if any, fixed-ratio types have progressed past the prototype staqe. This is somewhat surprising in view of the outstanding ability of traction drives to provide smnoth, aufet power transfer at extremely high or low speeds with good efficiency. They seem particularly well suited for hiqh-speed machine tools, pump drives, and other turbomachinery. In other industrial applications they offer potential cost advantages because tracticn rollers should not be much more expensive to manufacture in ouant ity than ordinary rollers in roller bearings.

In terms of earlinr work on fixed-ratio traction orives, the oevelopmental effort at General Motors Research Laboratories on the ir planetary traction drive (as described by Hewko (37)) was perhaps the most complete. Several of these drives were built and tested, including a 6-to-1 ratio, 373-kW unit for a torpedo and a 3.5-to-1 ratio, 75-kW test drive. This last drive expibited better efficiency and lower noise than a comparahle planetary qear set (37).

Interest in fixed-ratio traction drives is also high outside of the United States. Tests were recently conducted in Japan on a planetary traction drive of a construction similar to the General Motors unit for use with a gas-turbine auxilliary propulsion unit (APII) system (38). Planetary traction drives have also been studied in Finland.

The traction drives described thus far have a simple, single. row planet-roller format. For drives like these the number of load sharing planets is inversely related to the speed ratio. For example. a four-planet drive would have a maximum spead ratio of 6.8 before the planets interfered. A five-planet drive would be limited to a ratio of 4.8 and so on. $A$ remedy to the speed ratio and planet number limitations of simple, single-row planetary systems was devised by Nasvyt is (39). His drive system used the sun and ring-roller of the simple planetary traction drive, but replaced the single row of equal dianeter planetrollers with two or more rows of "stepped" or dual-diceter planets. With this new "multlroller" arrangement. practical speed rat los of 250 to 1 could be obtained in a single stage with three planet rows. Furthermore, the number of planets carrying the load in parallel could be areatly increased for a quen ratio. This resulted in a significant reduction in individual roller contact loading with a corresponding improvement in toroue capacity and fatigue life. In (39) Nasvyt is reports the test results for several versions of his multiroller drive. The first drive tested was a 373-kW (500-hp) torpedo drive of three-planet row construction with a reduction ratio of 48.2 and an input speed of $53000 \mathrm{rpm}$. The outside diameter of the drive itself was $43 \mathrm{~cm}(17 \mathrm{in})$ and it weighed just $93 \mathrm{C} N(210 \mathrm{lb})$ including its lightweight magnesium housing. It demonstrated a mechanical efficiency above 95 percent. To invest iqate ultrahigh-speed operation, Nasvyt is tested a $3.7-\mathrm{kW}(5-\mathrm{hp})$, three-t ow, 120-to-1 ratio speed increaser. The drive was preloaded and operated without toraue at $480000 \mathrm{rpm}$ for $15 \mathrm{~min}$ and $\mathrm{ran}$ for 43 consecutive hours at $360000 \mathrm{rpm}$ without lubrication but with air cooling. Two back-to-back drives were operated for $180 \mathrm{hr}$ at speeds varying from 1000 to $120000 \mathrm{rpm}$ and back to $1000 \mathrm{rpm}$. They transmitted between 1.5 and $2.2 \mathrm{~kW} \mathrm{(2} \mathrm{and} 3 \mathrm{hp})$. Another $3.7-\mathrm{kW}(5-\mathrm{hp})$. three-row speed increaser, with a speed ratio of 50 , was tested for more than $5 \mathrm{hr}$ at the full rated speed of $150000 \mathrm{rpm}$ with oil-mist lubrication and air coolin. It successfully transmitted $3.7 \mathrm{~kW}$ ( $5 \mathrm{hp}$ ) at 86 percent effictency (39).

The basic geometry of the Nasvyt is traction (Nasyutrac) drive is shown in Fig. 13. Two rows of stepped planet-rollers are contained between the concentric, high-speed sun roller and low-speed ring rollers. In the drive shown the planet rollers do not orbit but are arounded to the case through relatively low-speed and lightly loaded reaction bearings that are contained in the outer planet row only. The high-speed sun-roller and other planet bearings have been eliminated. The sunroller and first row rollers float freely in three-point contact with adjacent rollers for location. Because of this floating roller construction, an excellent force balance situation exists even with thermal or mechanical housing distortion or with slight mismatches in roller dimensions.

Based on the inherent qualitles of the Nasvytrac drive, a MSA program was inftiated (40) to paranetrically test two versions of the drive. These drives of nominally 14-to-1 rat io were tested at speeds to $73000 \mathrm{rpm}$ and pomer levels to $180 \mathrm{~kW}$. Paranetric tests mere iso conducted with the Masurtis drive retrofitted to an automotive gas-turbine engine. The drives exhibited good performance, with nominal peak efficiency of 94 to 96 percent and a maximum speed loss due to creep of approximately 3.5 percent. The drive package slze of approximately $25 \mathrm{~cm}$ in diemer by $11 \mathrm{~cm}$ in width (excluding shafting) and total wight of about $26 \mathrm{~kg}(58 \mathrm{lb})$ makes the Nasurtrac drive. wth a rated wean iffe of bout $12000 \mathrm{hr}$ at $75 \mathrm{kH}$ and $75000 \mathrm{rpm}$, size competitive with the best commercial gear ortve systems (23). 


\section{ORIGINAL PAQE OF POOR QUALITY}

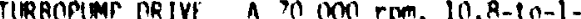
reduct lon-ratio Nasuverai drive righino fuse 4 ko was desloned and hutle for a Inno-life. rocket-engine ptem arive sustem to drtue the low-speed liould-axvoen and liauld-hudrogen

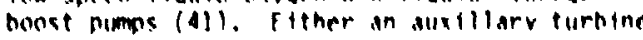
or a gear drive off the main numb can be usect. lise of an aurlllary lurhine combllicates the destan, while gear drives were not well sulted for this anolication hecause they more Dadly in a matter of ? min or so in ihls hostlle crmaente enviroment. This fell far short of the lo-hr life requtrement envisioned for future. reuseatile rockel angines. The relatively low sliding characterist tis of the Masurtrac drive. coupled with its demonserated athlity to run for leng periods of time unluhricated, make it an excellent candidate for thls application. srelliminary tests on this drive in lloutd oxven. including tests in which the drive was reoedtedly accelerated under full power (15 kW) to $70 \mathrm{~mm} \mathrm{rpm}$ in h-sec intervals, showed it to nerform sat isfactorily (41). Cimulative operat ing times un to an hour have heen recorded. Future mork is needed to redize the lo-hr life goal. hut the notent ial of this transmission for this apolication has heen clearly demonstrater. HYAR In TRAMSMISSIOM - Current work with varlattons of the insurtis traction-drive concept are underway at MASA. A recently fahrlcated. in-kH (GM-ho) hellcopter main rotor transentssicn combines the best features of gears with traction rnllers (4?). This experimental "hubrid" transmission, which offers potential cost, nolse, and rellability hanefits, is currentiv under test (F/a. 14:. Thts transmission carries 58 percent more power in test packaoe that is only ?2 percent heavier than the production OH-58 hellcopter gear box it simulates. In a hioh ratio version. to be tested shortiy, the hytrid transmission reduces the engine's power turhine shaft speed of $36000 \mathrm{rm}$ down th the rotor speed of $147 \mathrm{rpm}$ in a single hutid stege plus a hevel gear mesh. Thts permits the elimination of the nose gearbox on the engine. The net result is a predicted 6 percent increase in system power-to-wetght rat io. A 300 percent or areater increase in rellabllity is iso expected based on traction roller fat ique life estimates.

The demefits of this transalsston are ettributed to the hyorid's un tave geometrical configuration. Eear pinions are affixed to the ends of rollers in the outer row. The pinions, In turn, mesh with collector ring gear (or bull gear) wilch is normally atteched to the low spend output or rotor shaft in this case. The nigh torous capecity of the drive per unit wighe : due. In port. to the hloh mumer parallel loed paths in the find imgh. Another contributing fector is the lares nutuct lon ratio, on the order of 10-to-l. cechteved across the final mash wich enables the high spend traction roller section to carry relotively in 11 torwe locds.
An additional benefit of integroting gears with iraction rollers is the ability of the rollers to equalize the load sharing between the gear ninions through traction "creep". creen is the small difference in veloctty. aenerally less ih-t 0.5 percent, hetween the surfaces of the driver and driven rollers due to cilroue transfor. In the hybrid drive, if one of the pinions is carrving mire load than the others then the roller to wich it is attached will experience a slight ly higher creep rate. allowing the load to equalize. Thus, the trection rollers perform an important secondary function as a torque splitting mechanism. The similtanenus combination of high ris: 10 , htgh number of redundant load paths and a high degree of lnad shartino in the final gear mes" is an imonrtant feature of the hyorid concept not shared hy conventinnal epicyclic gearing.

AOVANCÉ APPL ICATIOWS - Work is now underwav on hutrid and pure-traction Masvyt is drives for several advanced appllcations: one such apolication is for wind turbines mere a low cost hut hlohiy reliable speed increase is needed to drive the hlah-speed alternator. Also. tests are now heing conducted on 160 ho infinitely variahle ratio Nasurt is drive, but the performance data has not yet been finalized. Another promisino area of investlaction for traction drives is as servo-control. positioning mechanisms. such as those used in robotics and in various manufarturing operations. Potent ial hemefits include zero backlash. Iow torowe ripple. high torsional stiffness, abllity to run dry (no lubrication system). high reduction rat io in single stage and compect stre. Space application of traction mechanism is iso under consideration. These are few of the areas where basic technology is being sought. PROMISING YAR IABLE SPEFn DRIVES - Taking advan'sge of the latest technology. several destaners have attempted to develoo traction CVT's for automotive uss. The potenttal of tmproving the cliy fuel intleage 20 to 25 percent. or nore, of cars nonmily equiloped with threeor four-speed automatic transmissions (43) or of doubling the fuel wileage in the case of flymeel eoulpoed cars i44) has on the mujor incentive for the resurgence in autamotive or research and developinent. These applteat tons represent a significant challenge, since cempectmess, effictency, cost, and reltedlity are all at a prention.

Perbury CrT - Ome such autemot ive effort Is that being conulueted by at Techmoloy, ltd. formerly Brltish leyiand on a Pertury. coublecavity toroical arive. This concept is rather old and wil-explored, as ment loned earlter. having bean Investlgated by the cemeral moten Research Laboratory in the early sos cad late sos, demonstrated in a 1934 Aust in-Mayes, later In 1957 Mlliman-Minx, and alse in a leis Fend Pinto bue with offeet roliers.

In 1977 Luces Aerosence in Emlend cheted the Perbury dife for minteining censtent iro euncy of the AC semrators on the sidiey 


\section{ORIGINAL PAGE IS \\ OF FOOR QUALITY}

Hawker Harrier VSTOL fet fighter. This single cavity. toroidal irtue is suitable for driving aircraft nenerators having output rating: up to $30 \mathrm{kVA}$. More than ?h vears before this. Avco Lycomtng, in the U. 5.. Also offered a line of mechanical consiant-speed drives based on the toroidal iraction.-drive princlole. They were used on several alrcraft in the 50s, including the nouglas A-4f fighter. hut have long since been discontinued.

In the case of the Leyland-perhury automtive CVT (F/Q. 15), the double-toraldal drive cavitles have six tiltable transfer rollers between input and nutput torolds. A hydratulicaliv controlled linkage sustem can tilt these rollers from one extreme posttion in another. By combining this toroidal drive with a two-range. outout planetary gear system, the overall transmission ratio ranqe is areat ly expanded.

The BL / Perbury transmisston was installed in a medium size test car having a fourcylinder, 6o-kW engine. The test car showed fuel mileage improvement of 15 to 20 percent for an average mix of European driving (45). Also, acceleration t tmes were comparable with a manual transmission car driven by a skllled driver having in percent hiqher power to weloht ratio. However, the fiture production picture for this transmission is not clear. Vadatec CVT - A promising traction CVT that $\bar{s}$ of a rather new vintage is the nutating drive being developed by Vadetec Corn. (46). As shown in Fla. If, a double-conical-roller assembly, complete with an sutomat ic loadino mechanism. is mounted at an angle in a drive cylinder that te driven by the input shaft. As the input shaft rotates. the double-cones perform a nutating motion and at the same time are forced to rotate about their own axis as they make drive contact with a pair of moveable control rinos. These rinos are arounded to the housing but can be axtally moved together or apart. A gear pinion attached to the end of the cone shaft meshes with the output ring gear. By varying the axtal position of the control rings, the rolling radius of the cones can be symchronously changed. This, in turn, causes change in rotational speed of the cone shaft pinion and hence vartes the transalssions out put speed. A couple f Vadatec CVT's have alresdy been bullt and tested. One of these prototypes has shown successful operation as part of tractor drive train. Although this cransutssion is stlll in the development and acceptance stage. It is a good eximple of the new breed of traction drive.

other Traction CVT's - In addition to the aforewintioned cettvites, the ir are a nuther of additional traction CVT developments that have been reported on recently. These Include the Fafnir plandery. cone rolier type cri. dincted toward the moblle coulpment artet up to cbout 37-kH (50-ho) (47): the Al Researeh dual cavity torotidal drive (40); and the cales micoln con-rolier evi (43). These last two trensatsstons me carried to prelinthery design stege under a Mas contricet for oOE to develop CVT's for use in advanced electric vehicles $(48)$.

\section{CONCLIINING REMARKS}

The evolut ton of traction-drive technology has been traced over the past 100 years. Some of the more prominent events in the development of iraction drives appears in Table 1 . This list is by no means intended to he comprehens fve hut, rather, to give the reader some appreciation of the scope of activities leading to iraction drives of today.

The earliest of traction drives, constructed of wood, leather, or fiber-covered disks running in dry contact, found first use in factory eauipment befo-e the turn of the century. The abllity of traction drives to smoothly and effictently vary speed made them natural choices as main transmissions for several early vintage cars. such as those produced by Cartercar. Sears. Lambert, and Metz. Apparently, durablilty problems with the softmaterial-covered dists used in these drives foreshortened their comerctal success. In the 1020s traction drives eoulpoed with oil lubricated, hardened, steel rollers started to appear. These drives had much greater power capac ity, and by the 1930 s several industi lal adjustabie speed tract ton drives were being marketed both here and in Europe. About this time, there were several projects to develop toroidal traction car transmissions, notably the Hayes and later. the Perbury efforts in England and the General motors ' work in the United States. In the 1940s modern lubricat ion and fat ique theories for rolling-contact lements kers developed, and these mere later adapted to the design of traction drtves. In the 1950 s work began on tdentifying flulds with hlah traction propert les and experiments on how these flutds actually behaved within the tract lon contact. A basic understanding was aiso obtained on how the fluld flim within the contact was compressed into a thin, stiff, tensclous solid-like flim ecross mich considerable toroue transfer could safely occur. By the end of the 1960s, high-euality bearting steels and traction fluids were comerclally avalloble. The power capacity of traction drives using the new steels and fluids virtually iripled, in the 1970s improved trection models and fet iguitfe prediction methods wre developed. This all led to the develogment of a nw nemetion of traction drives - drives with bright potential role to play in the power trensmission industry.

In 1900 the Power Tranedistion and earing Comittee of Asint took anjor step in re coonizing the potent tal vicolitty of erection drives by estobilshing a cubedittes to follow the develogints in the techmoleay for these transalsstons. A prtenry function of this subconittes is to assist in the discenination of technology miated to trection dpives con to foster the ir potential use in industry. 
In conclusion, field experience has been gathered by industrial traction-drive manufacturers, some of whom have beien mak ing trac$t$ ion drives for more than 40 years. However. traction-drive technology is relatively yound. The latest generation of traction drives has reached a high level of technic 31 readiness. As these drives find their way into industrial service and as work cont inues in the laboratories, further improvements and increased usage of these drfies $c$ an be expected.

\section{REF ERENCES}

1. S. H. Loewenthal, "A Historical Perspective on "Traction Drives and Related Technology," in Advanced Power Transmiss ion Technology," MASA CP-2210, Fischer, G.K., ed., 1982, pp. 79-108

2. F. Yeaple, Metal-to-Metal Traction Drives Now Have a New Lease on Life." Product Engineer ing, Vol. 42, No. 15, October 1971 , pp. 33-37.

3. R. W. Carson, "New and Better Traction Drtves are Here," Machlne Design, Vol. 46, No. 10, Apri1 18, 1974, Dp. 148-155.

4. D. McCormick, "Traction Drives Move to Higher Powers," Desian Engineerina. December 1980, pp. 35-39.

5. L. 0. Hewko, "Traction Drives and The ir Potential Role in Energy Conservation." Presented at the Joint ASLE Energy-Sources Technology Conference, New Or leans, LA, Feb. 1980 .

6. R. W. Carson, "100 Years in Revtew: Industrial Traction Drives. "Power Iransmission Design, Yol. 19, No. 10, October 1977. Pp. 99-100.

7. T. G. Fellows, et al.. "Perbury Cont inuously Variable Ratio Transmission." in a Advances in Autamobile Englneering." "Pt. I1, Oxford: Pergamon Press, 1964, Dp. 123-142.

8. P. Benjemin, Mppleton's Cycloped la of Applied Mechanics." Vol. II, New York: D. Appleton and Co., 1860 , pp. 36-37.

9. F. Clymer, "Historical Motor Scrapbook." Vols. 1 and 2, Los Angeles: Clymer Motor Publications, 1945.

10. A. P. Sloan, my Years with General Motors." New York: Coubleday and Co., Inc.. 1964.

11. D. F. Car1s and R. A. RIChardson, EngineTrunsentssion Relationships for Hion Effictency." SAE Transactions, Vol. 61. 1953. pp. $81-96$.

12. "Improved Technology is Giving an 01d Prin. ciple a Jive," Monsanto Magazine. Sumer 1974, pp. 14-16.

13. R. W. Carson, "Focus on Traction Orives: 10 Sears of Traction Orives." Power Transulssion Desten, Vol. 17. Mo. 5, May 1975. p. 84 and 8.

14. F. G. Perry. "Twe Perbury Transission." Asui Paoer io. 00-6T-22, mareh 1800.

15. R. M. Carson ufocus on Trection Orives." Power Trenseisston Design, Vol. 17, No. 3. march 1975, $09.48-49$
16. R. W. Carson, "Today's Traction Drives," Power Transmission Design, Vol. 17, No. 11, November 1975, DD. 41-49.

17. P. Cahn-Speyer, "Mechanical Infinitely $V$ ir lable Speed Drives." Engtneers' Oiger" Vol. 13, No. 2, February 1957, pp. 41-4!.

18. 0. Z. Dvorak, "Your Guide to Variable-. Mechanical Drives," Product Engineerin... Vol. 34, December 1963, pp. 63-74.

19. A. N. Grubin, "Fundamentsis of the Hydrodynamic Theory of Lubrication of Heavily loaded Cylindrical Surfaces," In "Invest 1gation of the Contact of Machine Compcnents." Kh. F. Ketova, Ed.. Translation of Russian 8ook No. 30, Central Sclentific Institute for Technology and Mechanical Engineering, Moscow, +949 . Chapter 2. (Avallable from Department of Sctentific and Industrial Research. Great Britain, Trans 1. CTS-235 and Special Libraries Association, Trans?. R-3554.)

20. G. Lundberg and A. Palmaren, "Dynamtc Capacity of Rolling Bearings," Ingen foersvetenskapsak ademi an, Hand linger, No. 196, 1947

21. J. J. Coy, S. H. Loewenthal, and E. V. Zaretsky. "Fatigue LIfe Analysis for Traction Drivas with Application to a Toroidal Type Geometry," MASA TN D-8362, 1976.

22. D. A. Rohn, S. H. Loewent'al, and J. J. Coy. "Simpitified Fat igue Life Analys is for Traction Drive Contacts," Journal of Mechanical Desion, Vol. 103, No. 2, Aprtl 1981, pp. $430-439$.

23. D. A. Rohn, S. H. Loewenthal, and J. J. Coy, "Sizing Criterla for Traction Drtves." In "Advanced Power Transinission Technology," MSA CP-2210, F techer, 6.K. ed., 198x. pp. 229-316.

24. T. B. Lane. "The lubrication of Friction Drives." Lubrication Engineer. Vol. 13. February 1957, DP. 85-88.

25. L. O. Hewko, F. G. Rounds, Jr., and R. L. Scott. "Tractive Capactity and Efficlency of Rolling Contacts," In "Rolling Contact Phenomena." J. B. Blowell, ed. Amsterden: Elsevier, 1962. pp. 157-185.

26. M. H. Haseltine, I. M. Duling, D. S. Gates, P. E. Hagstrom, and R. J. Stemose, "Design and Development of Flutds for frection and Friction Tyoe Transilsstons," SAE Paper 710837 , October 1971.

27. H. C. Hemen, R. M. Sehts1a, L. C. O. Eroemmeghe, and V. H. Eash, "Symthet Ic Fluids for High Capacity Trection Orives." ASLE Transactions, Vol. 13, No, 2, 1970. po. $105-116$.

28. R. J. Parker, A. H. Ham, and S. H.

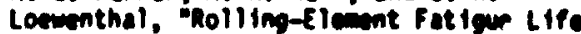
With Trection Flulds and Autemetic Transmission Fluid in a Migh-Saced Rolling-

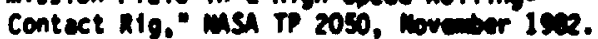

29. H. Gequenmier. Imwest teat loms of Trective Fore frensitssion in Voricble Trection Drives in the ares of Elastehyonodymic Lubrication," Ph.D. Otseartation, Pectriteal University of minteh, July 1977. 


\section{ORICINAL PAGE IS \\ OF POOR QUALITY}

30. E. N. 8amberqer, "Life Adjustment Factors fon Ball and Roller Bearinas - An Englneering Gulde." New York: American Society of Mechanical Engineers, 1971.

31. S. Y. Poon. "Some ra culations to Assess the Effect of Spin on the Tractive Capacity of Rolling Contact Drives," Proceeding Institation of Mechanical Engineers (London). Vol. 185, No. 76/71, 1970. 1015-102?

32. S. Linqard, "Tractions at the Spinninq Point Contacts of a Variable Ratio Friction Orfve," Tribology International, Vol. 7. october 1974, pp. 228-234.

33. K. L. Johnson and J. L. Tevaarwerk, "Shear Behavior of Elastrohydrodynamic 011 Films," Proceedings of the Royal Soc'et, !Londor.), Series A., Vol. 356, No. 1685, Auqust 1977. pp. 215-236.

34. J. L. Tevaarwerk, "Traction Drive Performance Prediction for the Johnson and Tevaarwerk Traction Mode1," NASA TP-:530. 1979.

35. J. L. Tevaarwerk, "Traction Contact Performance Evaluation at High Speeds," DOE/MASA/ 0035-1, MASA CR-165226, September 198:

36. S. H. Loewenthal and D. A. Rohn, "Elastic Model of the Traction Behavior of Two Traction Lubricants," ASLE Pieprint No. 83-AM-8A-2. Apr 111983

37. L. O. Hewko, "Roller Traction Drive Unit for Extremely Quiet Power Transmission." Journal of Hydronautics, Vol. 2, No. 3. July 1968, pp. 160-167.

38. L. Hakamura, A. Sato, H. Okano, and T. Sasak1. "A Development of a Traction Ro!ler System for a Gas Turbine Driven APU," SAE Paper No. 790106, February 1979.
39. A. L. Nasuyt is, "Mult 1roller Planetary Friction Drives," SAE Paper No. 660763. October 1966.

40. S. H. Loewentha1, N. E. Anderson, and D. A. Rohn. "Evaluation of a Hiqh Performance Fixed-Ratio Traction Drive," Journal of Mechanical Design, Vol. 103, No. 27. April 1981 , pp. 410-422.

41. 5. Meyer and R. E. Connelly, "Traction Drive for Cryogentc Boost Punp," MASA TM-81704, 1981 .

42. A. L. Nasyyt is and G. White, "Hybrid Geared Traction T-ansmission," in "Advanced Power Transmisston Technology," ASA CP-2210, Fischer, G. K., ed. 1982, pp. 161-172.

43. R. R. Radtke, $i$. E. Unnewehr, and R. J. Freedman. "Optimization of a Cont inuously Varisble Transmission with Emission Constraints," SAE Paper No. 810107, February 1981.

44. S. Strauch, "Flywhel Systems for Vehicles," Proceedings of the Electric and Hybrid Advanced Technology Seminar, December 8-9, 1980, Californta Insitute of Technology. Pasadena, pp. 219-236.

49. P. W. R. Stubbs, "The Development of a Perbury Traction Transmission for Motor Car Applications," Journal of Mechanical Design, Vol. 103, No. 4, Jaruary 1981, Dp. 29-40.

45. Y. Kemper and L. Elfes, "A Continuously Variable Traction Drtve for Heary-Duty Agricultural and Industrial Applications." SAE Paper No. 810948, September 1981.

47. T. W. Dickinson, "Development of Variable Speed Transmission for Light Tractors." SAE Paper No. 770749, September 1977.

48. R. J. Parker, S. H. Loewenthal, and 6. $r$ $F$ ischer, Design Studies of Cont inuous Variable Transmisstens for Electric Ventcles," SAE Paper No. 810410, 1981.

Table 1. - Limited Chronology of iraction Drive Developments

Date

\begin{tabular}{|c|c|}
\hline 62 & 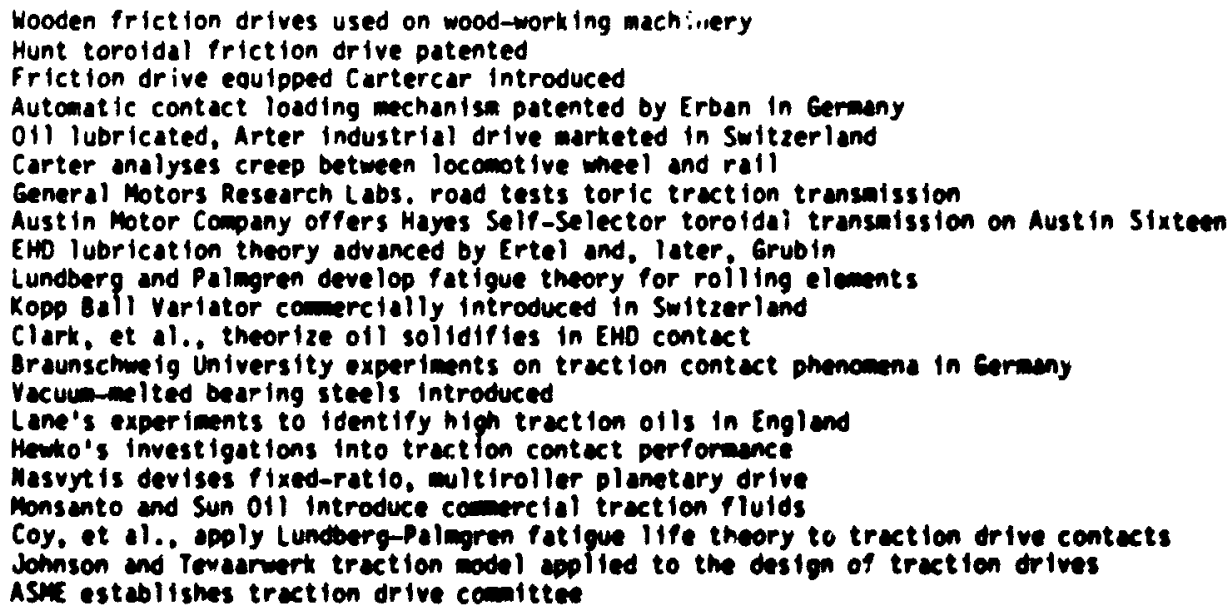 \\
\hline
\end{tabular}




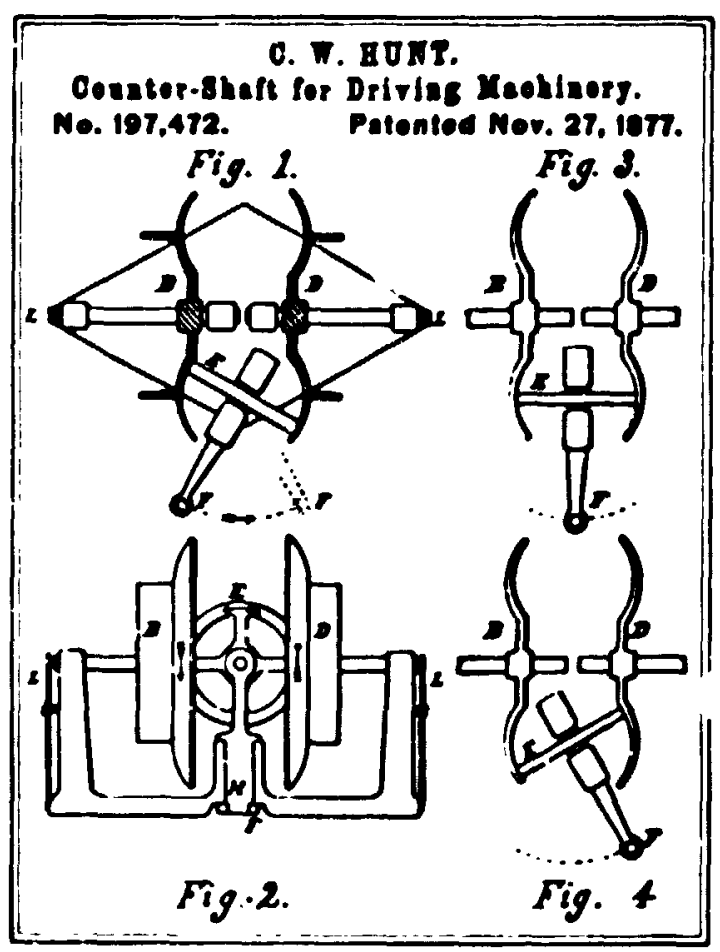

Figure 1. - Hunt's 1877 toroidal friction drive (ref. 6).

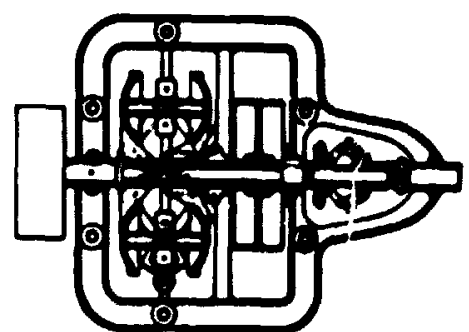

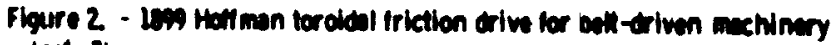
(ra. 7). 


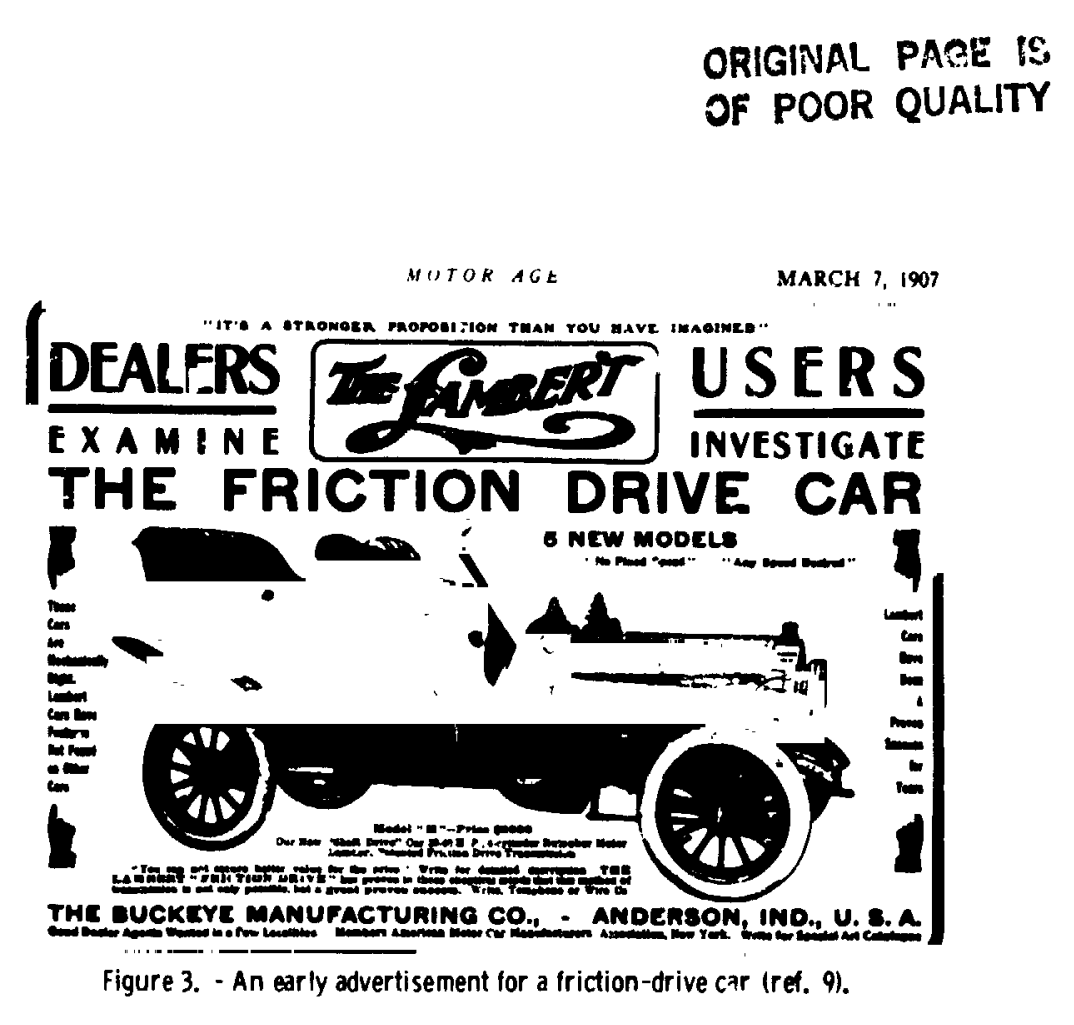


ORIGINAL PAGE IS

OF POOR QUALITY

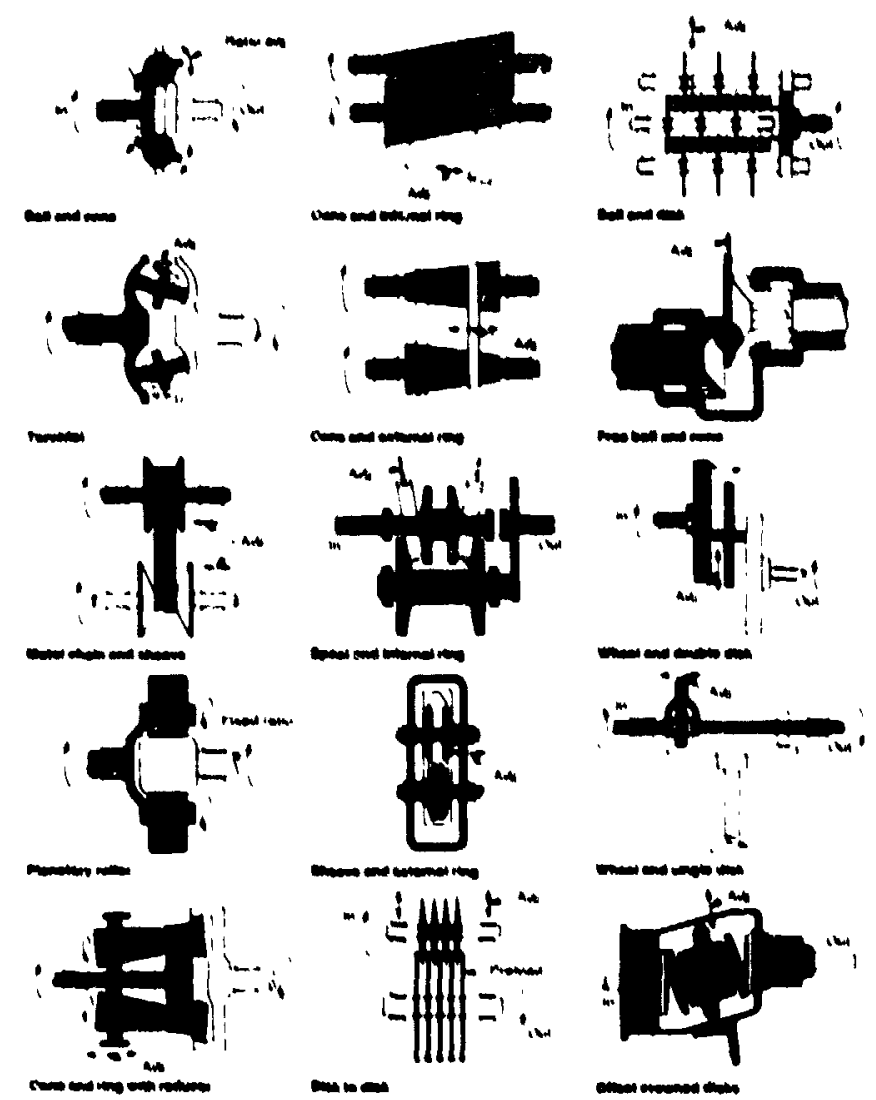

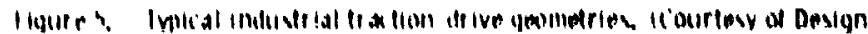
Inqinoering (rel. $\therefore$

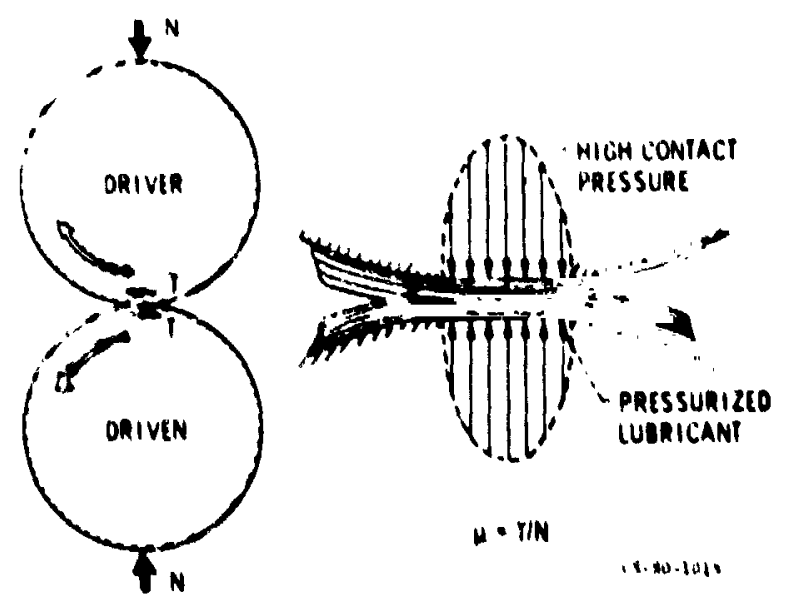

Flgure 6. - Power transfer through : ictlon. 
ORIGINAL PAGE IS

OF POOR QUALITY
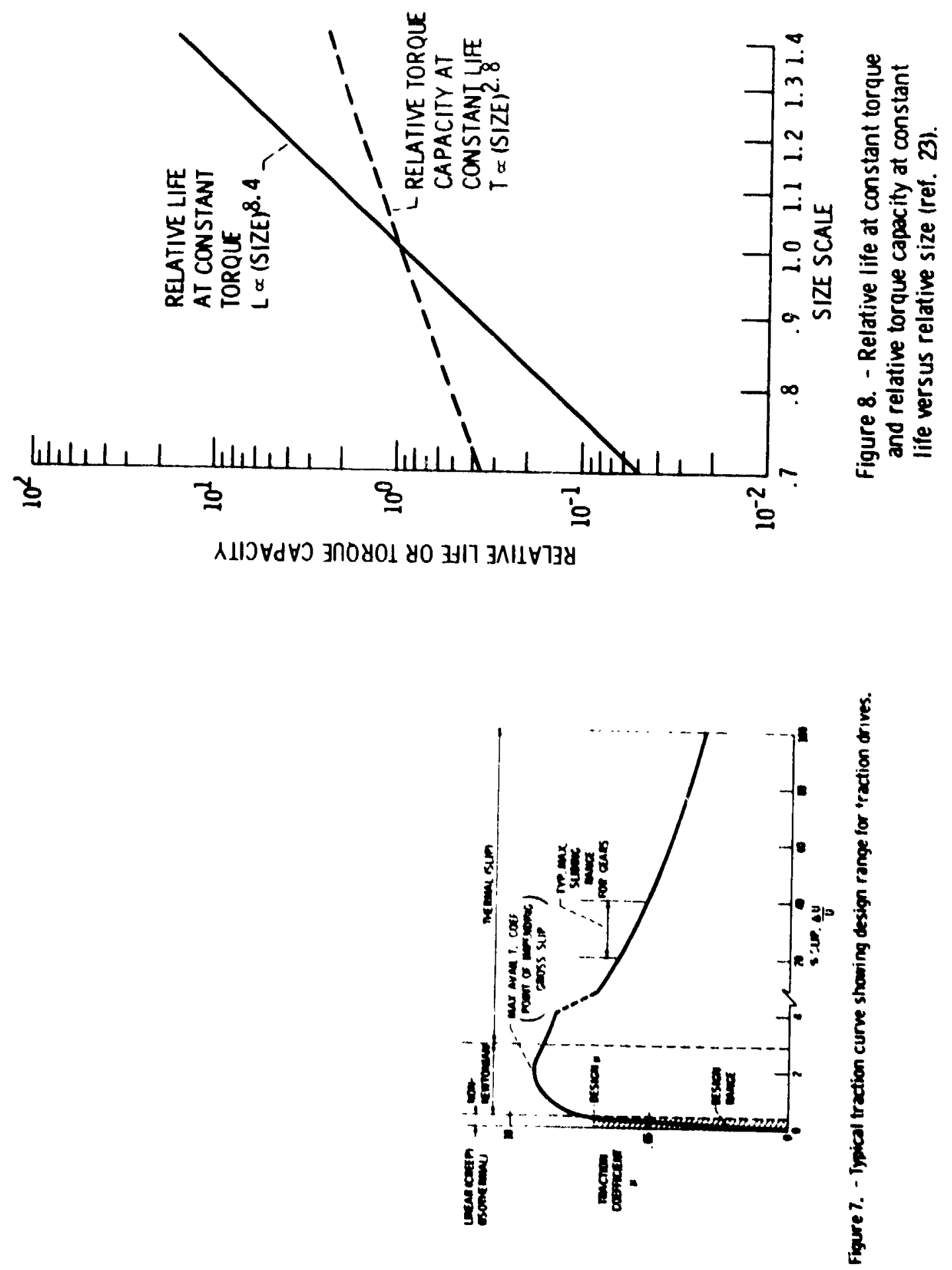
EFFECT OF TRACTION COEFFICIENT ON

TRACTION DRIVE LIFE, DIAMETER

AND TORQUE CAPACITY

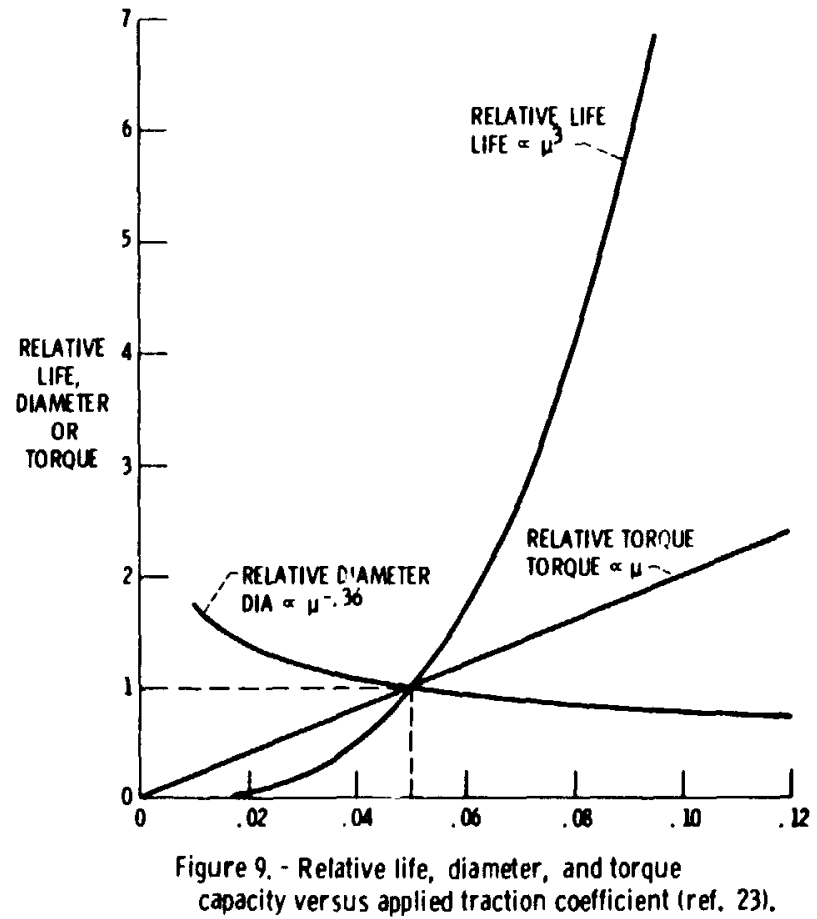

LOW PRESSURE, HICH STIZCD

HIGH PRESSURE, LOW SPEED

MAXIMUM HERTZ PRESS SP. $-1.09 \mathrm{GPa}$

SURFACE VELOCITY $\bullet 8.3 \mathrm{~m} / \mathrm{sec}$

MAXIMUM HERIZ PRES SURE - 1 \&GPA

OII IN TIMPERA IURE - SOOC

SURFACE VELOCIIY $-0.83 \mathrm{~m} / \mathrm{seC}$

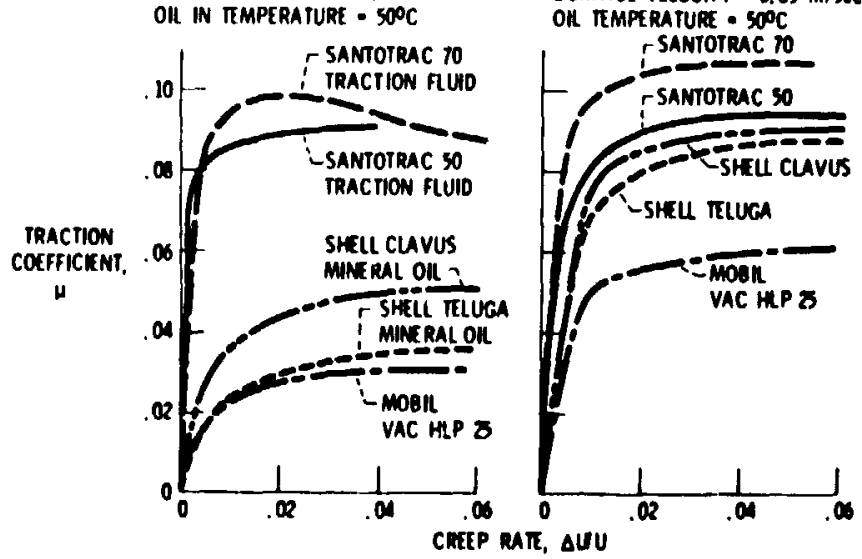

Figure 10. - Traction characteristics of a traction fluid compared with mineral oils (ref. 29). 


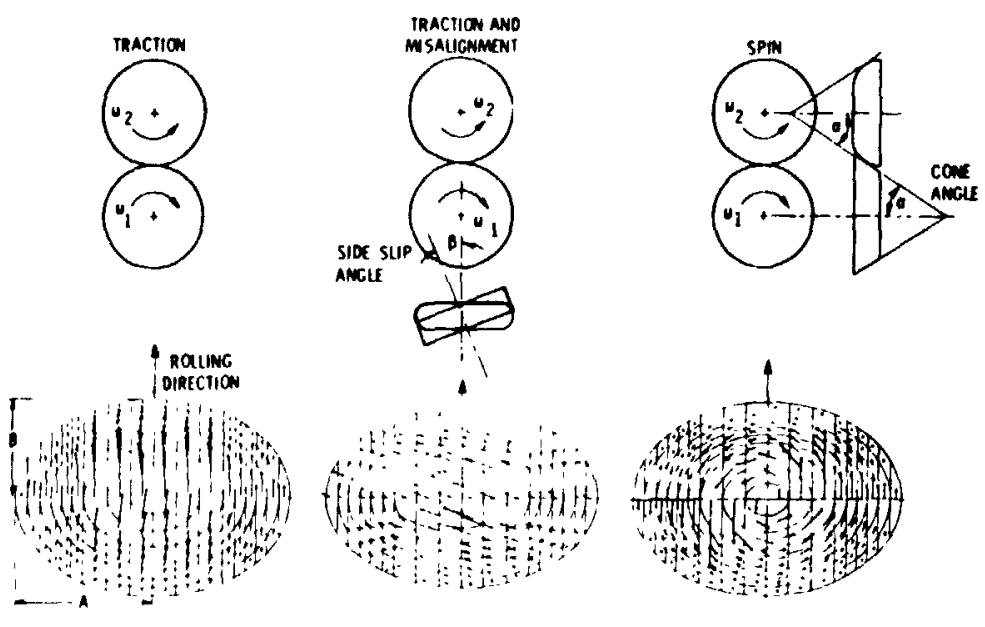

Figure 11. - Effect of misalinement and spin on contact traction force vectors.

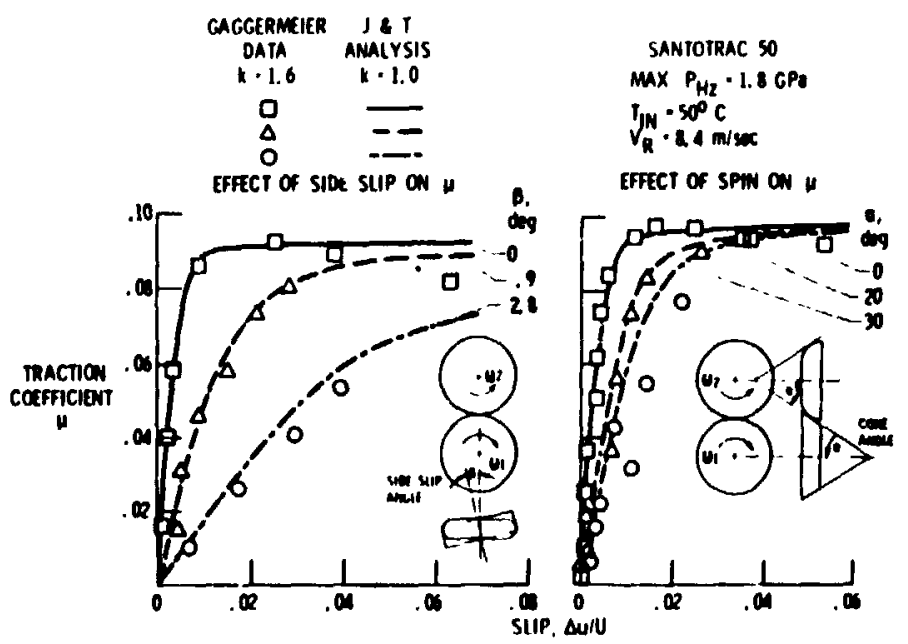

Figure 12: - Comparison of Johnson and Tevaarwerk analysis (ref. 48) with Gagger meir test data (ref. 29). 
ORIGINAL PAGE IS

OF POOR QUALITY
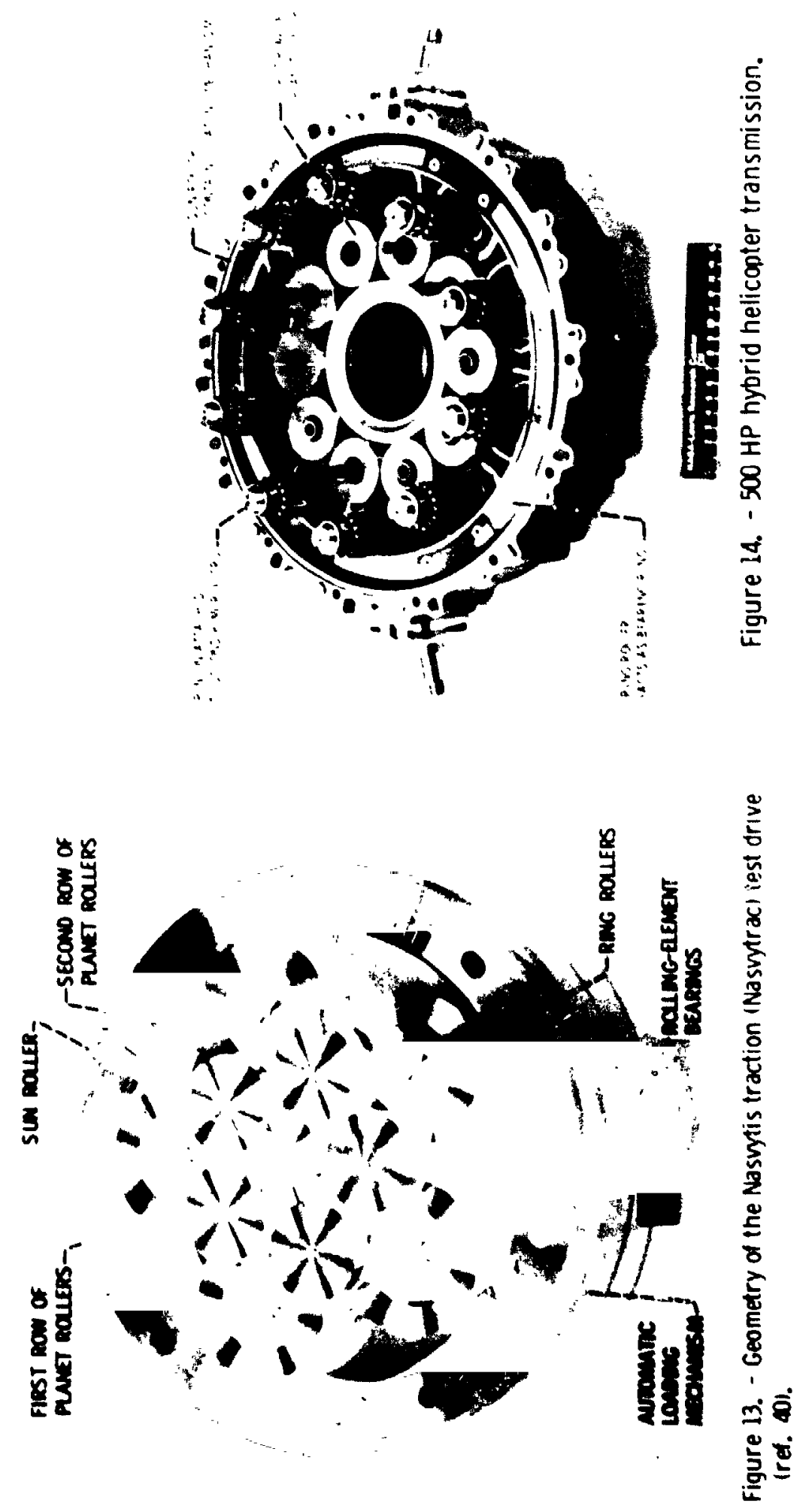


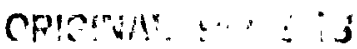

of POUR Quality

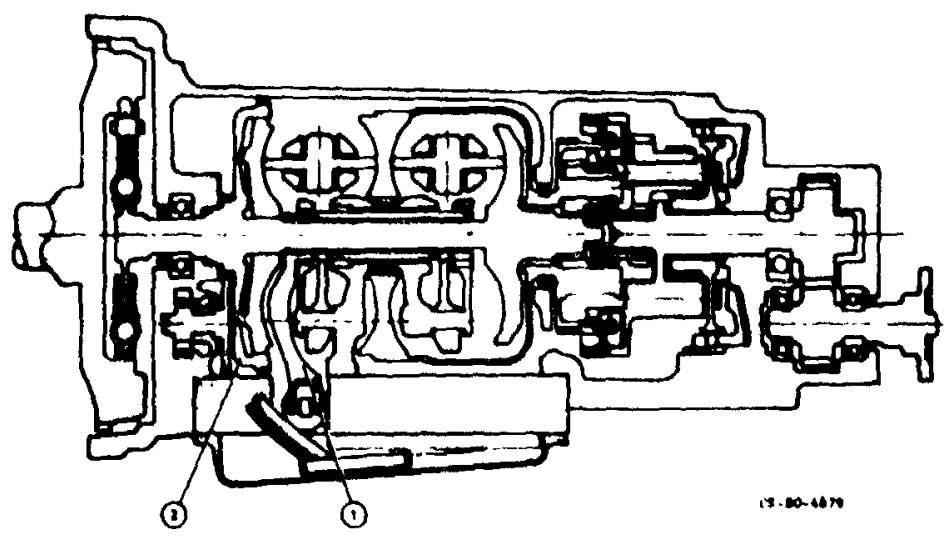

Fiqure 15. Rl Tecmologviperburvtration (VI, en kw passenger car lest installation (ref. fs).

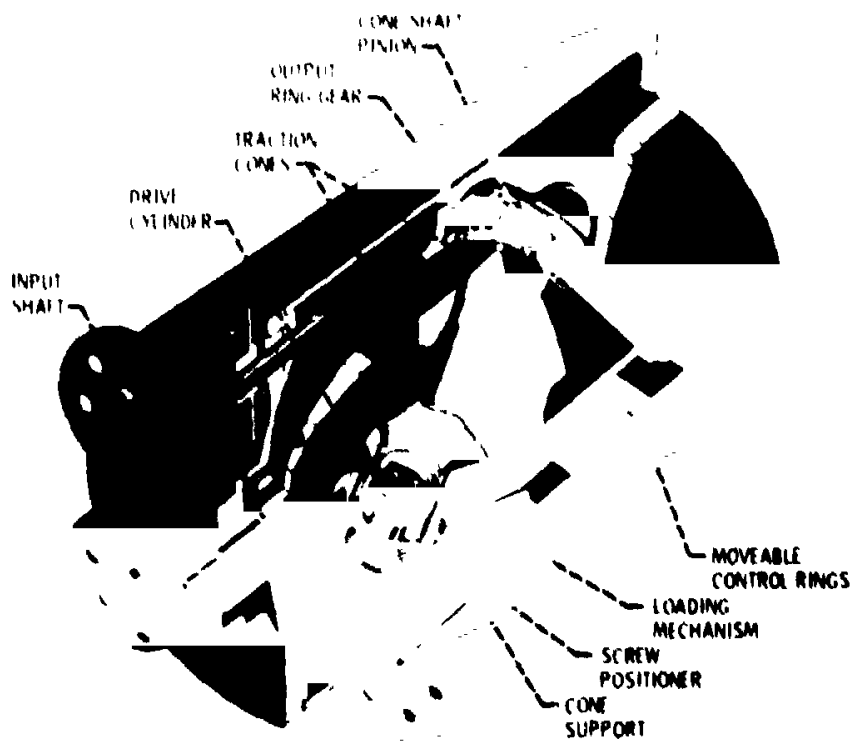

Figure 16. - Vadetec nutating traction CVT. ICourtesy ol Vadetec Corp., Troy, Michigan. 1 